\title{
Application of the whoqol-bref instrument in oncological patients rehabilitated with bucomaxylofacial prosthesis
}

\begin{abstract}
The incidence of oral cancer in Brazil is considered one of the highest in the world. In surgical treatments, where part of the maxilla, mandible, and tongue is removed, the maxillofacial prosthesis is used as a rehabilitation treatment. It is considered that patients undergoing surgical treatment of head and neck, when prostheticized, will present an improvement in the quality of life.
\end{abstract}

Objective: To relate the demographic, lifestyle, and clinical aspects to the Physical, Psychological, Social Relations and Environment domains of the WHOQOL-bref quality of life instrument in cancer patients treated surgically and rehabilitated with maxillofacial prostheses.

Method: This is a retrospective observational study, consisting of medical records of 189 patients, aged over 18 years, of both sexes, rehabilitated with maxillofacial prostheses. The data were recorded in an Excel spreadsheet, and the variables were considered: demographic, clinical, comorbidities, habits, and history of diseases. The statistical analysis considered the numerical frequency and percentage of the findings, and for the relationship between the variables, non-parametric tests were used $(\mathrm{p}<0.05)$.

Results: When relating the variables to the Domains, we observed a record of inferior quality of life in patients under 60 years of age. In the analysis by Domains, lower quality of life was recorded for women and the Psychological and Environment Domains; being under 60 and the Environment Domain; consume medication and show four or more clinical signs and symptoms and the Physical Domain, and mention of mental disorders and the Psychological Domain.

Conclusion: Buccomaxillofacial prostheses become an essential therapeutic resource in the rehabilitation process and provide improvements in the quality of life of these patients, guaranteeing their social reintegration, minimizing functional, aesthetic, and psychological disorders and, despite the difficulties suffered during the treatment. The positive impact of therapy in FOSP, as well as the targeted public policies, produces a positive view of the new reality of the patient and guarantees a better quality of life.
Volume 6 Issue I - 202 I

\section{Daniella Spacassassi Centurion, Léslie} Piccolotto Ferreira

Faculdade de Ciências Humanas e da Saúde, Departamento de Teorias e Métodos em Fonoaudiologia e Fisioterapia, Programa de Estudos Pós-Graduados em Fonoaudiologia, Pontifícia Universidade Católica de São Paulo, Brasil

Correspondence: Daniella spacassassi centurion, Faculdade de Ciências Humanas e da Saúde, Departamento de Teorias e Métodos em Fonoaudiologia e Fisioterapia. Programa de Estudos Pós-Graduados em Fonoaudiologia, Pontifícia Universidade Católica de São Paulo, Brasil,Av. Gal Mac Arthur, 1645 Apto 44 Gardênia, Email danispaca@gmail.com

Received: December 08, 2020 | Published: January 28, 2021

\section{Introduction}

Cancer is a multifactorial chronic disease, resulting from the interaction of risk factors that affect the processes of control of cell proliferation and growth. ${ }^{1}$ The incidence of oral cavity cancer in Brazil is one of the highest in the world, being the fifth most incident in men and the seventh in women. ${ }^{2}$ The changes affect the main stomatognathic functions (such as breathing and swallowing) and body image. ${ }^{3}$ Among the therapeutic methods available, surgical resections, radiotherapy, and chemotherapy ${ }^{4}$ stand out, which directly affect patients' quality of life. ${ }^{5}$ In surgical treatments, in which part of the maxilla, mandible, or tongue is removed, the maxillofacial prosthesis ${ }^{6}$ is used as a rehabilitation treatment, which directly impacts your physical and psychological recovery. ${ }^{5-8}$ The instruments used to assess the quality of life, such as WHOQOL-bref, can cover the entire disease process, from its discovery to the end of treatment., ${ }^{9}, 10$ The present study intends to relate the impact on the quality of life, using the instrument applied to patients diagnosed with oral cavity cancer, submitted to oral cavity resections, and rehabilitated with a maxillofacial prosthesis.

\section{Methods}

This is a retrospective observational study, in partnership with the Pontifical Catholic University of São Paulo (PUC-SP) and the Fundação Oncocentro de São Paulo (FOSP). 189 medical records of patients over 18 years old, of both sexes, attended at the FOSP Rehabilitation Department, diagnosed with oral cavity cancer, were part of this study. This research was approved under CAEE: 17440819.9.0000.5482.

The WHOQOL-bref instrument was applied in two stages, and for this study, we considered the moment after the fitting. The variables considered were: sociodemographic, clinical data, and data related to the analyzed instrument (WHOQOL-bref). The statistical analysis considered the numerical frequency and percentage of the findings and for the relationship between the variables, non-parametric tests were used $(\mathrm{p}<0.05)$.

\section{Results and discussion}

The results showed that there is a predominance of males (64\%), with an average age of 60 years, as found in the literature ${ }^{11-15}$ the 
diagnosis is usually made late and shows the need for improvements in health promotion and disease prevention. Regarding habits, $127(70.2 \%)$ denied a current smoking history and $151(83.4 \%)$ of alcoholism. ${ }^{13-17}$ The most indicated prosthetic rehabilitation was the maxillary prostheses combined with the mandibular prostheses. This makes possible the reinsertion of this individual in social life, improving their quality of life. ${ }^{18,19}$ As for the Domains, the quality compromise was shown in: Physical for those who consume medication and refer to the presence of four or more symptoms; ${ }^{21-23}$ Psychological, for the female sex, which denotes the fragility of this population during the treatment ${ }^{20,24,25}$ and Environment, for the female sex and patients under 60 years old, who, as described in the literature ${ }^{26,27}$ shows the need to implement a primary prevention program for young patients. The results of this research may assist in the planning of actions among health professionals, to be developed with patients diagnosed with oral cavity cancer, rehabilitated with a maxillofacial prosthesis, implementing activities that consider issues related to the quality of life.

\section{Conclusion}

The same surgery that mutilates and deforms can be concurrently seen as the best solution for the disease and the consequent recovery of quality of life. Patients seem to attribute new meanings to this therapy, even seeing a positive perception of their quality of life.

\section{Acknowledgments}

None.

\section{Conflicts of interest}

No potential conflict of interest relevant to this article was reported.

\section{References}

1. Almeida MJR, Oliveira MC. Avaliação da qualidade de vida de pacientes diagnosticados com câncer de boca, faringe e laringe atendidos na unidade de alta complexidade em oncologia (UNACON) e MULTICLIN de Feira de Santana-BA. Anais Seminário de Iniciação Científica. 2019;22(9):110-113.

2. INCA. Incidência de Câncer no Brasil. Rio de Janeiro: Estimativa 2018 Instituto Nacional do Câncer; 2018.

3. Genden EM, Devin Okay, Marita T, et al. Comparison of functional and quality-of-life outcomes in patients with and without palatomaxillary reconstruction: a preliminary report. Arché Otolaryngol Head Neck Surg. 2003:129(7):775-780.

4. Petito G. Papilomavírus humano (HPV) em carcinomas de cavidade oral e orofaringe na região central do Brasil. Brazilian Journal of Otorhinolaryngology. 2017;83(1):38-44.

5. Lopes AB. Fatores modificadores da qualidade de vida em pacientes oncológicos em tratamento quimioterápico. Revista Médica de Minas Gerais. 2016;26(1):41-46.

6. Contis SM, Pérez IM. Necesidad de próteses bucomaxillofacialen pacientes atendidos em la consulta de somatoprótesis. Rev Cuba Medi Mili. 2006;35(3):0-3

7. Araújo SSC, Dalva MPP, Maria PP, et al. Avaliação da condição de saúde bucal e da qualidade de vida de pacientes com câncer de cabeça e pescoço atendidos em um hospital de Porto Alegre. Rev Bras de Cancerologia. 2009;55(9):129-138.
8. Aguiar L, André RM, Elder L, et al. Obturador palatino: confecção de uma prótese não convencional - relato de caso. Revista da Faculdade de Odontologia de Passo Fundo, Passo Fundo. 2013;18(1):125-129.

9. Zandonai AP, Cardozo FMC, Nieto ING, et al. Qualidade de vida nos pacientes oncológicos: revisão integrativa da literatura latino-americana. Rev Eletrônica Enferm. 2010;12(3):554-561.

10. Whoqol Group. Development of the World Health Organization WHOQOL-brefquality of life assessment. Psychological medicine. 1998;28(3):551-558.

11. Santos L.C.O., et al. Câncer bucal: amostra populacional do estado de Alagoas em hospital de referência. Braz J Otorhinolaryngol. 2009;75(9):524-529.

12. Lambert R. Epidemiology of cancer from the oral cavity an doropharynx. Eur J Gastroenterol Hepatol. 2011;23(8):633-641.

13. Freire JCP. Incidência de neoplasias malignas orais nas regiões brasileiras e capitais do Nordeste. Arch Health Invest. 2017;6(11):535-539.

14. Silva NCL, ZA Barros, Soares JN, et al. Toque terapêutico e qualidade de vida em pacientes oncológicos. Id online Rev Mult Psic. 2018;12(4):784 792.

15. Silva GC, Silva NC, Silva CC, et al. Perfil epidemiológico de pacientes com câncer de cabeça e pescoço em um hospital referência da região sul de Santa Catarina. Arquivos Catarinenses de Medicina. 2020;49(1):66-77.

16. Malta DC. Uso e exposição à fumaça do tabaco no Brasil: resultados da Pesquisa Nacional de Saúde. Epidemiologia e Serviços de Saúde. 2015;24:239-248.

17. Brasil. Decreto $\mathrm{n}^{\circ} 8.262$, de 31 de maio de 2014. Altera o Decreto $\mathrm{n}^{\circ}$ 2.018, de $1^{\circ}$ de outubro de 1996 , que regulamenta a Lei ${ }^{\circ} 9.294$, de 15 de julho de 1996. Diário Oficial da República Federativa do Brasil, Brasília (DF), 2014.1:1

18. Kusterer LEFL., GM Paraguassú, VSM Silva. et al. Reabilitação com obturador maxilar após cirurgia oncológica: relato de casos. Revista de Cirurgia e Traumatologia Buco-maxilo-facial. 2012;12(4):9-16.

19. Rodrigues RG, Reabilitação com prótese bucomaxilofacial: revisão de literatura. Brazilian Journal of Otorhinolaryngology. 2019;5(1):20-27.

20. Costa NP. Avaliação do dano corporal no tratamento do cancro da cavidade oral e estruturas anexas. Tese de doutorado, Portugal. 2017.

21. Rafhi-Ferreira RE, Pires MLN, Soares MRZ, et al. Sono, qualidade de vida e depressão em mulheres no pós-tratamento de câncer de mama. Psicol Reflex Crit Porto Alegre. 2012;25(3):506-513.

22. Galbiatti, ALS, Junior JAP, Jose VM, et al. Head and neck cancer: causes, prevention and treatment. Brazilian Journal of Otorhinolaryngology. 2013;79(2):239-247.

23. Binotto $\mathrm{M}$, Schwartsmann $\mathrm{G}$. Qualidade de vida relacionada à saúde de pacientes com câncer de mama: revisão integrativa da literatura. Revista Brasileira de Cancerologia. 2020;66(1).

24. Chaxim TS, Zacharias, DG. Aspectos psicológicos paciente oncológico e seu sistema familiar. Anais do Salão de Ensino e de Extensão. 2016:124.

25. Xavier EDCL. Diagnósticos de Enfermagem em cuidados paliativos oncológicos segundo diagrama de abordagem multidimensional. Enfermagem em Foco. 2019;10(3):152-157.

26. Teixeira AKM, Almeida MEL, Holanda ME, et al. Carcinoma espinocelular da cavidade bucal: um estudo epidemiológico na Santa Casa de Misericórdia de Fortaleza. Revbrascancerol. 2019;55(3):229-236.

27. MaltaDC. Uso e exposição à fumaça do tabaco no Brasil: resultados da Pesquisa Nacional de Saúde. Epidemiologia e Serviços de Saúde. 2015;24:239-248. 